\title{
Aristotelianism and African Political Predicament: New
}

\section{Implications and Imperatives}

\author{
Elijah Okon John ${ }^{1 *} \&$ Joseph Ajuluchukwu Uka ${ }^{1}$ \\ ${ }^{1}$ Department of Philosophy, University of Uyo, Uyo, Akwa Ibom State, Nigeria \\ *Elijah Okon John, E-mail: elijahjohn@uniuyo.edu.ng
}

\begin{abstract}
Aristotle's socio-political theory emphasizes the belief that human beings are naturally political. Aristotelian ideals that the political life of a free citizen is a sovereign state which provides for the well-being of the citizenry is the highest form of life. Thus, his idea of free citizenship immediately introduces the concept of limitations between citizens - the free and the not free, the masters and the slave. The consequence of his political theory is the introduction of inequality among the members of the society but the question is: was Aristotle right in justifying social inequality? The answer to it embodies the major issues of this work. How we can evaluate Aristotle's positive and negative socio-political theories is one of the concerns of this paper. Effort will be made to critically explicate the good aspects of his theory as well as drawing a synthesis from the critique of the condemnable aspects of Aristotle's political philosophy in fashioning out a formidable route for African political leaders.
\end{abstract}

\section{Keywords}

Aristotelianism, African politics, African solidarity, framework for African resurgence, African political predicament

\section{Introduction}

As trite as it has become, the term "African predicament" still enjoys the headlines of many writings on African political issues and problems today. Africa has variously been described as the "home of darkness", "the land of want" and the "zone of death", among many others. The atmosphere of uncertainty, despair, darkness and pessimism pervades the colonial and post-colonial Africa. These are some of the features of what is rather known as African predicament. There are two sets of questions that can be asked about the state of political affairs in Africa today. The first concerns itself with the effects of colonialism brought by the West and the accompanying evils of their mission, namely: what are the visible impacts of colonialism to the psyche of Africans? What did the West actually intend to achieve by destroying African value systems, traditional heritages and the ontological understanding of being in the community of beings. The concern here also is to determine the forms of their operation, the insincerity in granting independence hurriedly to nations that they have so grossly been ripped off 
its soul and guiding it to the only route of unavoidable failure. The other set of questions concern the reactions of Africans to the unholy marriage with the West. What are the possible gains and lessons? Do Africans themselves gain anything or learn any lesson therefrom? For how long will Africa live with the scares and/or wounds inflicted on her by the West or through their self-inflicted ones? How can Africa assist herself and most importantly how has Africa inflicted more wounds on herself? What is the route to Africa's true emancipation?

This paper is concerned with the second set of questions, namely; the possibility of putting African on a sound and surer footing in the comity of nations. It is the position of this paper that Africa is in dire need of true emancipation. O'Rouke is perfectly right to remark that "Man developed in Africa. But he has not continued to do so there" (Onah, 1998, p. 166). Disease, hunger, illiteracy, political instability, corruption, xenophobia, terrorism and other extended list of woes and calamities stalk Africa in the face. Comparatively, Africa is the poorest continent in the globe. According to Ukoli, life in Africa is characterized by the terrible trinity of poverty, ignorance and disease (1981, p. 45). It is therefore unfortunate that Africa has solely relied on developed nations for their existence and progression without being ashamed to be cajoled as a continent living on charity. This mentality debars Africa from recording any significant progress since the inception of her independence. The continued dependence of Africa is clearly seen in the implementation of counteractive or counter-productive international economic programmes, territorial disagreements, military armament and ceaseless loans and the result is obvious. Africa for so long still remains a toddler, a pawn in global political and technological chessboard, a testing and dumping ground for any and everything unwanted. Africa cannot pull any force in that she has no barging or bargaining power and of less economic control of their immense natural resources. This basically constitutes the predicament of African continent. A continent has unarguably come to a crossroad; wealthiest in natural resources and poorest in all ramifications.

However, some cogent and superior thoughts of philosophers have significantly influenced the directions of many societies and political changes in many epochs. At a certain level, the philosophy of Plato especially his concept of the philosopher-kings became a serious challenge for people to constantly examine and endeavour to enlighten the society about the best political order and ideology in the business of governance. This also provoked the need to provide theoretical foundations for them. Hence, the history of philosophy is replete with leading philosophers who have made substantial contributions to the development of various ideologies and nations. Thoughts of certain philosophers like Plato, Augustine, Aquinas, Marx, Machiavelli, Kant, Rousseau, etc. have had major influence on their immediate societies and then the society at large. Rousseau and his influence on French enlightenment or revolution and Locke's ideas as reflected on the representative government easily come to mind. It is along this line that we engage Aristotle's political philosophy in addressing issues arising from African predicament. This approach constitutes the main focus of this paper and in attempt to address it, the work is segmented into three areas; thus, section one highlights the basic concepts as 
well as the positive aspects of Aristotle's theory_politeia and eudaemonia. In section two, the article examines the master-slave relationship and the inequality inherent in Aristotle's notion of citizenship especially as this affects women. Section three handles the new implications, imperatives and the concluding remarks embedded in the thesis of these papers. To achieve this end, it will be vital to consider briefly the concept of Aristotelianism used in this work.

\section{Aristotelianism: Meaning and Interpretations}

Aristotelianism is a derivative from Aristotle, the Greek philosopher. According to Stumpf, Aristotle was born in 384 BC in Stagyra on the Northern Coast of Thrace (1971, p. 84). He was one of the most influential philosophers of all ages. He is credited as the first to create a comprehensive system of philosophy with broad areas in ethics, aesthetics, politics, metaphysics, logic and sciences. His own school known as Peripatetic School was influential especially in the medieval era and Scholasticism; added to this is the fact that Averroism and Avicennism are the offshoots of Aristotelianism. It must be noted that Aristotelianism is therefore a tradition in philosophy that takes its defining inspiration from the works of Aristotle. However, the concept had a narrower meaning in the medieval era when Aristotle was the centre of every philosophical discuss. Unlike his predecessor Plato, his philosophical contributions are more practical and down-to-earth in structure and content. His copious works encompasses a wide area in ethics, metaphysics, aesthetics, logic, epistemology, political theories and sciences.

Ozumba points this picture lucidly thus: “... Aristotle as a worthy pupil ... merely fished out the missing link in Plato's philosophy and in his intellectual humility and love for his master, decided to bridge the gap or supply the missing link. What Aristotle did was to provide the physical substructure on which the metaphysical superstructure of Plato's view can comfortably rest on" (2000, p. 3). Aristotle's philosophical exploration is so vast that there is hardly any philosophical position that has no root in or link to Aristotle's work. Be it as it may, our concern here is on his contributions to the political ambient and how ideals sifted from his political theory can assist African leaders. Our attempt in this paper is not a review of Aristotelianism, but the application of his ideas to solve African peculiar political problems and this will hopefully guide African political leaders in their attempt to govern African nations.

\section{Aristotle's Political Theory of "Solidarity" and Well-Being}

Aristotle in his political philosophy sees the state as an organism, which means that a state is a living being that exists for some ends or purposes (Moore \& Bruder, 1999, p. 68). Aristotle believes that the state exists to guide its citizens to achieve the good life; in this regard, he has no stereotype idea of the state. Accordingly, he identifies three kinds of good government, which when misused become three kinds of bad government. According to Omoregbe, Aristotle identifies kingship, aristocracy and polity 
as the good kind of government while tyranny, oligarchy and democracy are the bad forms (1990, p. 119). These kinds of government will accordingly depend on the kind of constitution they are based. So there can be government by one, by few or by many depending on the kind that suits the society at a given time. In his Politics, Aristotle (1962, p. 312) observes that individuals make up a family. Then the village consists of the families units. The coming together of many family units makes the village; while villages make up the state. With this, he demonstrates that by nature man is a political animal. The political society then exists to serve man's needs and to provide man with the means to attain the goal of life which for him is eudaemonia (translated often as happiness). Therefore, for Aristotle, the family is the basic aspect of society put in place by the law of nature to provide man's daily needs. Since the needs are not limited to daily ones which the family can provide, therefore, the village exists for that purpose. However, as the village is in itself not self-sufficient, a higher structure, namely: the state will be required. Consequently for him, the formation of the state is motivated by the need to assist man to achieve his end which is happiness or well-being.

Deductively, it follows that the existence of the state is premised on the necessity of man and the limited resources to achieving his end. One may quickly ask; what happens in a situation when the state fails to rise above the needs of man, as the case may sometimes be? Aristotle however does not comment directly on the issue. It appears that he anticipates only a strong and a virile state that can worth the name "state". This is why Aristotle's view runs thus: "In order to achieve the prime function of the state, Aristotle provides a regimented structure for the state. He maintains that the ability of the state to defend itself in war without much difficulty determines the size of the state" (John, 2009, p. 151).

One does not need to go far to see Aristotle's view of the origin, nature, functions and structure of a state. Two significant points can be deduced from here, and these are: stability and socialization man's social well-being. They are interrelated and they reinforce each other in Aristotle's idea of the state. The state has to be stable in order for the wellbeing of the citizenry to be guaranteed. Nwodo remarks that the situation under which Aristotle wrote in ancient Greece in many ways has a striving resemblance to Africa's situation today $(1998$, p. 59). The question of stability or instability was a reality in which the ancient Greek philosophers faced. But the situation is not unique to Africa; it is indeed a perennial and universal one.

From the ontological point of view, the ancient Greek philosophers were faced with the search for ultimate reality; the nature of things, the problem of one and many, and of motion and rest, of change and permanence. The lonians, the Eleatic school and the atomists, tried to explain reality from different points of view. Aristotle inherited the problem of instability which was far from a mere academic exercise for the ancient philosophers. The climate of strife and unrest was too known to them. In the days of Aristotle, the Athens and Spartans were always waging war against each other. Greece was equally at war with Persia. It was a world of internal as well as external strife with its attendant 
instability politically and economically. This explains why Plato had a place for soldiers in his organization of state in the Republic. So we can now understand too, why Aristotle sees the need to set up a politeia. Sinclair tells us that politeia, is broader than the English meaning of politics. Elaborating on the membership of politeia, Sinclair writes: "At this point, we shall remember that a politeia is essentially a collection of people ... a body of 'sound' men, united in their acceptance of all standards, moral and spiritual, intellectual and artistic, which belong to and are prescribed by the constitution by which they live" (Aristotle: Politics, 1962, p. 426).

Furthermore, Aristotle maintains that part of the functions of the state is to defend itself in war without difficulty. So for Aristotle, a politeia (politics) is set up for the purpose of eudaemonia. Armstrong describes eudaemonia as: "a word which may perhaps, best be translated "well-being"" (it is wider than our modern use of happiness which generally signifies a state of feeling, whereas eudaemonia is a state of complete general satisfactoriness; the eudaemonia not only feels happy, but all is really well with him) $(1965$, p. 101). In relating politeia to eudaemonia, Aristotle clearly expresses the need for the stability of the state in order to provide the social wellbeing of its citizenry. Another important point which Aristotle observes as a critique against his master, Plato, is that of power sharing. Aristotle faults Plato's ideal state with regards to retaining power in the hands of some people. Nwodo quoting Aristotle writes: "Risky too is Plato's way of appointing the rulers; they are to be always the same people. This is a sure source of faction, even among those of no standing to say nothing of those he calls warlike and spirited" (1998, p. 64).

Aristotle's argument is that power should not be a special reserve of some people alone as it will lead to rancour and fractionalization in the polity. For these reasons, he criticizes the idea of the rule of the philosopher-kings and proposes that citizenry should be able to decide the kind of constitution they will practice and the kind of government best suited for their situation. The end to which the politeia is set up in any case will be the eudaemonia - the well-being of man. Political stability for Aristotle therefore means the permanence and continuity of the comprehensive social structure that encompasses the whole organization of the state and the totality of its politics. In the modern parlance, this will embrace the economic, the legal, as well as the ethical structures of governance. Likewise, the social well-being in Aristotle's notion means not just the mere feeling of happiness rather the complete general satisfactoriness. This well-being has the template of permanence. To this effect, Sinclair has this to say on Aristotle's eudaemonia (well-being) when he writes: "It cannot be achieved in less than a complete life time ... And one day or indeed any brief period of felicity, does not make a man entirely and completely happy" (Aristotle, 1962, p. 39).

For want of better English equivalence, we have consciously interchanged social well-being with happiness to translate eudaemonia. Happiness for Aristotle is both a requirement and a necessity for every citizen regardless of his condition in society. However, realizing how difficult it will be for every citizen to be happy in the state, Aristotle remarks: "For happiness is a very different thing from 
evenness: two odd numbers added together make an even number, but two unhappy sections cannot add up to make a happy state" $(1962$, p. 79$)$. Aristotle therefore avers that it is the duty of the law giver to make the whole city happy, whereas it is not possible for all to be happy, at least the majority should be happy. One question that would easily crop to mind here is how can the slave be happy under the servitude of the master? Aristotle would seem to reply that such question would not arise, since according to that the master-slave relationship is to the advantage of the slave. We shall highlight more on this point in the next section. We now turn to Aristotle's position on slavery as well as the sub-ordination of women.

\section{Master-Slave Relationship}

Aristotle sees slave as a means to an end, that is, he categorizes the slave live tool used by the master for the purpose of productions the master owes slave as a piece of property. The slave is a tool meant for action, implying that he is a mere means to achieving the goal of his master. This piece of property - the slave is meant for action and manual task. In his very words, Aristotle remarks: "Any piece of property can be regarded as a tool enabling man to live, and his property is an assemblage of such tools: a slave is a sort of living piece of property; and like any other servant is a tool in charge of other tools" (Aristotle, 1962, pp. 64-65).

It is significant to note that Aristotelian slave is marked in terms of his physical characteristics. Amongst those features that a slave bears, Aristotle remarks thus: "Those whose condition is such that functioning is the use of their bodies and nothing better can be expected of them, those I say are slaves by nature; it is better for them ... to be ruled by a master" $(1962$, p. 69). Here, Aristotle does not only justify slavery but points to the fact that slavery is to the advantage of the slave. He anchors his argument on the assumption that humanity is classified under rational and irrational groups. Since the irrational for him are incapable of making sound judgment, they would naturally rely on the rational group for guidance. Hence the rational becomes the masters of the irrational who are by these same token slaves.

One question that will immediately confront a modern reader of Aristotle's classification of irrational and rational group would be; who are those groups that are briefed of rationality? Are they the morons or mentally disadvantaged members of the society? If they are, how could they undertake coordinated manual work? What are the criteria for accessing rationality for Aristotle? More so, do their circumstantial predicaments take away their humanity? Accordingly, he uses this criterion on physical attribute as he argues: "The use made of slaves hardly differs at all from that of the tamed animals: they both help with their bodies to supply our essential needs. It is then part of the nature's intention to make the bodies of free men to differ from those slaves, the latter is strong enough to be used for necessary task, the former erects and becomes useless for the life of a citizen of a state" (1962, p. 69).

What this means is that one can tell who a slave is by looking at the physical appearance. Does that 
equally translate to irrationality? Does the superiority of the physical or bodily physic make one irrational or vice versa? One wonders how such theories were arrived at. Was it by empirical observation or through psychological text?

\section{Aristotle on Women Subordination}

For Aristotle, the concept of citizenship is an exclusive reserve for those who take part in policy decisions and participate politically in shaping the society. And this kind of individuals is of the male folk. Aristotle vehemently argues: "A citizen is in general, one who shares in ruling ... So far as the best constitution is concerned, he is a man who is able and who chooses to rule and be ruled with a view of life that is in accordance with virtue" $(1962$, p. 213). The import of this position shows that other members of the society including women whether young or old are excluded from the class of citizenship. This, for Aristotle, is because women are naturally inferior to their male counterparts. This natural difference, therefore, makes it just and crucial for men to rule women. Furthermore, Aristotle argues that women lack the mental ability to participate in citizenship, hence he concludes that "the male are suited to rule than the female, unless conditions are quite contrary to nature" (1962, p. 92).

One thing is common, on the issue of the subordination of women and slavery, Aristotle however would hardly rise above his society on the issue of inferiority of women and the approval of slavery. Although it is worth noting that Aristotle declares that slaves should be set free upon their masters' death, but this, however, does not justify slavery. Aristotle believes slavery benefits both the slave and the slave owner. Accordingly, he argues that life of labour is demeaning and degrading, so those who must engage in manual labour are not able to be as virtuous as those who do not have to do such. He avers that slavery is natural institution and sees slaves as household possessions.

Aristotle argues that there are many hierarchies in nature and that those who are lower in natural hierarchy should be under the command of those who are higher. What this means is that Aristotle, on the same token which he assesses women's subordination and slavery he also would have approved of imperialism. Thus, he declares: "The male, unless constituted in some respects contrary to nature, is by nature more expert at leading than the female, and the elder and complete than the younger and incomplete. This means that it is natural for the male to rule: "The relation of male to female is the relation of superior to inferior and ruler to ruled" (1962, p. 321).

However, this was a general situation in Aristotle's era, as the Greeks held that women were inferior to men; thus, women were denied access to political participation. Implicitly, this can greatly stifle the knowledge and skills to be proficient in them. Greeks are not alone in this suppression of women as some traditional African practices had no place also for women in the society, except in the home front. Women's major role was to preserve what men acquired. However, some women even in such hostile traditions have struggled to raise their voices loud and in doing so, have raised the status of women folk and secured a special place for them in history. In Nigeria for instance, names like Queen Amina, 
Margaret Ekpo, Madam Ransom-Kuti and a few others easily comes to mind. This shows that no tradition or culture is absolutely static and stagnant. This is the reason we are strong in recommending that women should not relax and continue to enjoy their comfort zone. In as much as we subscribe for the thirty-five percent affirmation for women's participation in politics, women should not wait for the political positions to be allotted for them. They should make themselves available for all elective positions in Africa. By a conscious, concerted effort, the political space will gradually open up for them and who knows, the women folk are possible to populate it in no distant future.

It should be noted that Aristotle failed in his discussions on slaves to explicate on what woman's virtues look like, but it is clear that he believes that a man's superiority to woman is dictated by nature and cannot be overcome by customs or beliefs. We however, condemned this view as archaic and anachronistic. Culture is something dynamic and not anything to be classified as static. The difference Aristotle seeks to justify is more of the cultural biases than the natural subjugation. Women may by nature be of weaker constituent, but this does not translate to making them lower in rationality or inferior to the male folk.

Contemporary societies have shown women weighing powers politically and economically. Some women have done so well in positions of leadership and the indication is that if they are encouraged, the society will benefit from their rich contributions. This could be seen in various political positions that some women had held in the recent past in Britain, Germany, Portugal, Brazil, Argentina, India, Pakistan and more closely Liberia. Women participation in political activities should be encouraged in Africa. We have seen Aristotle's connection between politeia and eudaemonia; we have equally seen Aristotle's position on slavery and the place of the women in the society, it would also be relevant, in the spirit of eclectism, to sift what is expedient from his socio-political philosophy as see how it can be of benefit to Africa's contemporary political situation.

\section{The New Implications and Imperatives: Framework for African Political Resurgence and Solidarity}

The postcolonial Africa is embroiled in a critical search for a synthesis of political resurgence. The ideological posture of the West towards Africa's predicament such like religion and tribal conflicts, insurgency, political and administrative infantilism, slavery, colonialism and neo-colonialism in Africa, has received predominant critical evaluation from various points of view. Various thinkers argue that Africa is backward as a result of her predicament. That is, Wiredu in his representative voice writes: "But how can Africa do her own thinking when ... the minds of very many Africans remain colonized in the deepest reaches of their conceptual framework? ... Africa's problem of identity is a bottom philosophical problem" (1998, p. 22).

The implication of the trans-Atlantic slavery and colonialism, one of the greatest undoing of Africa has been seen as the result of traumatic, psychological impacts the West had on Africans. The tale of 
European dominance was so morbidly highlighted that African assumed, sometimes, the inferior position. This is why Africans cannot totally be exonerated from her problems. Some African thinkers have gone as far as painting in their works how the West cannot offer solutions to African problems and equally, how the injection of Western ideas into African culture is at the root of the continent's current predicament. While there is dearth of individuals making explicit cases for this line of reasoning, this paper, however, does not toe the same line of thought. One of the reasons for such posture is predicated on historical fact which suggests that military conquest or colonialism does not signpost a case of death penalty to the host societies. It is also a historical experience that while the Romans conquered the Greek military, the Greek re-conquered the Romans ideologically. The spread of Christianity which is the gateway to modern civilization remains a legacy of such experiment. It is equally true that under the very watch of African leaders, their erstwhile peers in misery in Asia, Latin America and Portugal moved away from "danger zone" leaving Africa behind.

African thinkers are unanimous in proposing a common united African front to tackle Africa's political and developmental challenges. They, however, differ on the approach of this goal. The re-awakening of the spirit of unity among African nations began in the twentieth century. This came in form of the promotion of pan-Africanism led by Marcus Garvey and others. Their task was to offer the succeeding generation of Africans the reason and hope to believe in Africa's bright future. Their passion was exuding with unquestionable and unflagging faith in a better tomorrow for Africa. Thus, their anthem states: "Black people or black race once enslaved, oppressed and humiliated in alien (and their home) lands would rise again to become architects of their history, and controllers of their own world" (Okolo, 1993, p. 153).

The above submission was the aspiration and hope that led to the independence of most African countries. Unfortunately, this enthusiasm was short-lived because after independence, the charged atmosphere was depilated; the hopes dashed and the dreams vanished. Since then, the post-independent Africa has had mountains of crises upon crises to deal with. From one nation to another, the story is similar. From the fragmentation of Somalia, civil war and famine in Ethiopia, genocide in Rwanda, internal conflicts in Senegal, Sudan, Zaire, Burundi, to tyranny and dictatorship in Uganda, and militancy in Nigeria, to mention by a few. There are some individuals who believe that leadership in their countries is their birth-right which only death can take away from them. Therefore the body or organization established to propel Africa to a common front had little or no effect in the face of these challenges. However, a promised alternative political structure on the template of a sound, well-articulated system and institutionalized changes in the political and economic arena came up in the form of African Union (AU) from the defunct Organization of African Unity (OAU). The concern of African Union is to make the present structure workable and to deliver the desired goals.

Accordingly, this work agrees with the suggestion of Anya (1981, p. 89) that African countries should appropriate those natural resources available to them prudently and equitably in order to fast-track the 
development of their scientific and technological potentials. He also believes that unless Africa takes seriously the issue of scientific and technological development, they will never get to the dreamed Promised Land. Gambari (1981, p. 69) opines that those nations in Africa that are blessed with abundant resources of all kinds should not only desist from permitting alien powers to interfere and control their destiny, but also be generous enough to share resources with other less privileged nations in the continent of African. As important as this point may be, it leaves much to be desired, because management of resources has been the bane of African leaders since independence. This explains why it is however, difficult to boast of a single African country that is self-sufficient. Agbakoba (1998, p. 238) argues that Africa's major challenge is an ideological one. He observes that Japan and China could survive the effect of colonialism because they drew a gap between what they accepted from their invaders and their rich culture of strong commitment to order, duty, loyalty, and harmony with a strong ethos that was critical to the West.

But Africa according to Abgakoba substantially accepts and embraces the western culture which they see as superior to theirs. Agbakoba is not done yet as he further maintains that Africa should have a focus in adapting their tradition to the western ideology. It is on the above basis that John (2009, pp. 158-159) supports the formulation of a continent wide socio-political thesis. For him, this project can only be realizable when African leaders know how to promote the solidarity of African nation-states through the platform of African Union (AU). For John, African leaders must understand that African culture is synergetic rather than parochial. Going further, he expresses faith in the project and operation of a common currency which he suggests should be taken beyond ECOWAS states to the entire Africa. This he argues would oil the socio-economic as well as strengthen the political ties among the member-states in Africa.

John's remark introduces a very important aspect of our discussion, namely: the template of solidarity. The issue of solidarity can never be overemphasized. Solidarity is a term derived from the Latin word solidus which means the whole, and the entire. Its French equivalence is solidarite which means the whole, union or fellowship arising from common responsibility, and interests as between members of a class or a body of persons or between classes, peoples or groups. Sociologically, solidarity means social cohesion. Resulting from the concept of solidarity, one must emphasis the need for the unity of purpose among members of a given class or group before solidarity could be achievable. The question now is: do we have such in Africa? How many Africans are versed with the happenings in other countries in Africa as we are versed with what happens in Europe and America? How many graduates from African Universities can comfortable mention the names of the fifty-four member countries in Africa? The problem is that if we do not know these facts as citizens, we may hardly know them even when we become leaders.

The issue of solidarity therefore, introduces a point we often relegate to the background, and this is the issue of continental consciousness. We must familiarize ourselves with not only our national 
consciousness but also with our continental consciousness. All the issues raised above will make a whole lot of sense when we begin to consciously give an introspective examination of events and issues in African continent. To this end, the celebrated dictum of Ali Mazrui aptly fits in here: "The greatest crime against our fellow men (and women) is not to hate them, but to be indifference to them; which is the essence of all inhumanities" (Aristotle, 1974, p. 67).

For Africa's survival and progress, we need to continue to re-organize ourselves at the national and continental levels. We must be aiming at creating general awareness of the need for solidarity, policies for socio-political and economic life for Africa and the determination of issues and problems affecting each area of the continent. From the historical recognition of our strengths and weaknesses to the understanding of present condition and seek the way forward through concerted and united efforts, the imperatives of African predicament become more pronounced and worrisome.

One must admit that Aristotle was right to observe that the size of the state must not be too small or too big but be of a manageable one. John in his erudite contribution observes that certain African states are not big enough to be independent in an exclusive sense of the word, making the cooperation and coalition absolutely necessary $(2009$, p. 158). It follows from Aristotle's position that the politeia is meant for the eudemonics. If the state is not capable of providing for the wellbeing of her citizenry, the only option left then is to seek for a stronger cooperation amongst states for the purposes of achieving the wellbeing of the citizens. Presently, with the possible exemption of South Africa and perhaps Egypt, no other country in Africa can boast of self-sufficiency even many years after independence.

The billions of dollars Nigeria received as loan and grant every year show how dependent the giant of Africa is even with the excess natural resources. It is a truism that every country in Africa is indebted to or look up to the western world for help. One can easily submit that this precarious situation of African continent is a product of poor leadership and this constitutes the major predicament facing her. It is worthy to note that sit-tight rulers in Africa are not helping matters. Every leader in African must see himself as a tenant in the corridors of power; or else, life in Africa will continue to be nasty, brutish, short, poor and retarded. Therefore, the option of political education becomes a necessity. Again, women should not wait for the political positions to be allotted to them. They should make themselves available for all elective positions in Africa.

\section{Conclusion}

The task of this paper was to unearth and proffer solutions to the unfortunate situation of Africa's socio-political life most often articulated under the now becoming overused term African predicament. With the events of her peculiar history, the paper argued that Africa being a problematic continent is a product of her response to the experience of colonialism, namely; new colonialism, rather than the effect of the colonialism itself. Thus, this work faced the onerous task of arguing for a fresh approach of African re-positioning based on socio-political contributions of Aristotle especially on the stability of 
the States and the well-being of the citizens in the continent. Aristotle's socio-political philosophy is however not infallible and sacrosanct. In this wise, we have debunked all negative elements of inequalities and social stratifications inherent in Aristotle's political philosophy, especially his theory of master-slave relationship that justifies slavery and the inequality between male and female that debases and weakens the women folk, which further gives credence to racism, exploitations, man in-humanity to man and other reprehensible injustices in all facets of African socio-economic and political ambience.

Unarguably, therefore, this work strongly maintained that the criteria for inequalities in the society have social and cultural rather than biological basis. The gender and racial differences and/or uniqueness cannot and should not be the basis of inequality in the society. More so, this write-up curiously and strongly made a case for all inclusive participation for everyone and/or women's active involvement in political activities in Africa. With the amendment of these two aspects of Aristotle's socio-political philosophy-stability of the States in providing for the wellbeing of the citizenry and striving for equality of all citizens in a free and fair polity, one only has to hope that the key to Africa's true emancipation that is anchored on the premise of social engineering and legitimations for all and sundry has arrived via Aristotelianism. The implication, therefore, is that African solidarity, social justices and effective governance in the continent (of Africa) cannot be toyed with any longer by neophytes if the assumptions and attendant recommendations are taken seriously by African socio-political leaders and thinkers.

\section{References}

Agbakoba, J. C. (1998). Towards a Philosophy of Technology and Development for Africa. In J. O. Oguejiofor (Ed.), Africa: Philosophy and Public Affairs (pp. 217-240). Enugu: Delta Publishers.

Anya, A. O. (1981). Science, Policy, Development and Geopolitics-A Nigerian Case Study. Ibadan Journal of Humanistic Studies, 2, 15-21.

Aristotle. (1962). The Politics (T. A. Sinclair, Trans.). New York: Penguin Books.

Armstrong, A. H. (1965). Introduction to Ancient Philosophy. London: Methuen.

Encyclopedia Britannica. (2015). Aristotelian. Retrieved May 12, 2015, from http://www.Philosophybasics.com/movements_aristotelianism.html

Gambari, I. A. (1981). The Third World as a Centre of Influence of Power. Ibadan Journal of Humanistic Studies, 2, 71.

Igwe, S. C. (2010). How Africa Underdeveloped Africa. Port Harcourt: Professional Publishers.

John, E. O. (2009). Man and the State: Issues in Socio-Political Philosophy. Uyo: Afahaide Publishers.

Mazrui, A. A. (1974). World Culture and the Black Experience. Seattle: University of Washington Press.

Moore, B. N., \& Bruder, K. (1999). Philosophy: The Power of Ideas. California: Mayfield Books. 
Nederman, C. J. (2014). The Meaning of Aristotelianism in Medieval Moral and Political Thought. Journal of History of Ideas. Retrieved from http://www.muse.jhu.edu/

Nwodo, C. S. (1998). Political Stability and Social Wellbeing in Aristotle's Political Philosophy: Its Relevance to the Nigerian Situation. In J. O. Oguejiofor (Ed.), Africa: Philosophy and Public Affairs (pp. 58-73). Enugu: Delta Publishers.

Okolo, C. B. (1993). African Social and Political Philosophy: Selected Essays. Nsukka: Filladu Publishers.

Omoregbe, J. I. (1990). Knowing Philosophy. Lagos: Joja Educational Research and Publication.

Onah, G. I. (1988). A Concept of Man for a Developing Continent: A Search. In J. O. Oguejiofor (Ed.), Africa: Philosophy and Public Affairs (pp. 166-184). Enugu: Delta Publishers.

Ozumba, G. O. (2011). Integrative Humanism and Complementary Reflection: A Comparative Analysis. Filosofia Theorectica. An African Journal of Invention and Ideas, 1(1), 151-170.

Stumpf, S. E. (1971). Philosophy: History and Problem. New York: McGraw Hill Books.

Ukoli, F. M. (1981). Towards an African Approach in Parasitology. Ibadan Journal of Humanistic Studies, 2, 77-85. 